\title{
PARACYTHERIDEA PUCKETTI NOM. NOV. FOR PARACYTHERIDEA INFLATA PUCKETT, 2008 (OSTRACODA, CRUSTACEA)
}

\author{
ANDRÉS SALAZAR-RÍOS (D) \\ Universidad de Caldas. Instituto de Investigaciones en Estratigrafía (IIES). Calle 65 \#26-10. \\ Edificio Orlando Sierra, Bloque B, $2^{\circ}$ piso. Manizales, Caldas, Colombia. \\ andresfelipe.salazar@ucaldas.edu.co

\section{LAURA BERNAL (D)} \\ Universidad de Caldas. Facultad de Ciencias Exactas y Naturales. Departamento de Ciencias Geológicas. Calle 65 \#26-10. \\ Edificio Orlando Sierra, Bloque B, $4^{\circ}$ piso. Manizales, Caldas, Colombia. \\ laura.601514047@ucaldas.edu.co
}

\begin{abstract}
Paracytheridea pucketti nom. nov. is proposed here for Paracytheridea inflata Puckett, 2008 because this species name is pre-occupied by Paracytheridea inflata Purper \& Ornellas, 1987.
\end{abstract}

Keywords: Ostracoda, Paracytheridea, nomen novum, Jamaica, Eocene, systematic paleontology.

\section{INTRODUCTION}

The ostracod genus Paracytheridea Mueller, 1894 is a common component of littoral to neritic environments worldwide. In the Americas it has been found both in tropical and temperate latitudes from the Cretaceous to the Recent (Benson, 1959; McKenzie \& Swain, 1967; Bold, 1988; Cronin, 1988; Browers, 1993; Coimbra et al., 1999b; Ballent \& Whatley, 2009; among others). In its wide temporal and geographical distribution, at least 33 species have been described for the genus in the Americas (see Brandão \& Karanovic, 2020 for a compilation of accepted species).

Puckett (2008) describes eight new ostracod species in the Eocene of Jamaica (Guys Hill Formation), one of them named as Paracytheridea inflata. However, this combination is pre-occupied by Paracytheridea inflata Purper \& Ornellas, 1987, described originally in the Recent equatorial and NE Brazilian shelf, but latterly reported southward this shelf as far as $\sim 22^{\circ} \mathrm{S}$ (Machado et al., 2020). Because of this primary homonymy (article 53.3 of ICZN, 2000), we propose the substitute name of Paracytheridea pucketti nom. nov. for Paracytheridea inflata Puckett, 2008, as defined in article 60.3 of the ICZN (2000).

\section{SYSTEMATIC PALEONTOLOGY}

For the supra-generic classification, the proposal of Horne et al. (2002) was followed.
Class OSTRACODA Latreille, 1806

Subclass PODOCOPA Sars, 1866

Order PODOCOPIDA Mueller, 1894

Suborder CYTHEROCOPINA Gründel, 1967

Superfamily CYTHEROIDEA Baird, 1850

Family PARACYTHERIDEIDAE Puri, 1957

Paracytheridea Mueller, 1894

Type species. Paracytheridea depressa Mueller, 1894

Paracytheridea pucketti nom. nov.

2008 Paracytheridea inflata Puckett, n. sp. pl. 1, figs, 1-7. non 1987 Paracytheridea inflata Purper \& Ornellas sp. nov. pl. 1, figs. 1-12.

non 1999a Paracytheridea inflata Purper \& Ornellas Coimbra et al., fig. 41.

non 2020 Paracytheridea inflata Purper \& Ornellas Machado et al., fig. $10 \mathrm{~N}$.

Derivation of name. Due to its discoverer, Dr. Terry Markham Puckett (University of Southern Mississippi).

Type material. National Museum of Natural History, USNM 534056-534057 (Puckett, 2008).

\section{ACKNOWLEDGEMENTS}

A. Salazar-Ríos thanks A. Pardo-Trujillo (Universidad de Caldas, Colombia) for his support when this manuscript was being written. We are grateful to J.C. Coimbra (Universidade Federal do Rio Grande do Sul, Brazil) for his kindness in sharing some of the works cited. We would also like to thank the editors of RBP (A.M. Ribeiro and M. Arai) and the two anonymous reviewers whose recommendations helped to significantly improve this manuscript. 


\section{REFERENCES}

Ballent, S.C. \& Whatley, R.C. 2009. Taxonomy and zoogeography of the Mesozoic Cytherurid Ostracoda from west-central Argentina. Palaeontology, 52:193-218. doi:10.1111/j.14754983.2008.00827.x

Benson, R.H. 1959. Ecology of Recent ostracodes of the Todos Santos Bay Region. Baja California. Mexico. University of Kansas Paleontological Contributions, 1:1-80.

Bold, W.A. 1988. Neogene paleontology in the northern Dominican Republic 7. The Subclass Ostracoda (Arthropoda: Crustacea). Bulletins of American Paleontology, 94:1-105.

Brandão, S.N. \& Karanovic, I. 2020. World Ostracoda database. Available at doi:10.14284/364; accessed on 07/10/2020.

Browers, E.M. 1993. Systematic paleontology of Quaternary ostracode assemblages from the Gulf of Alaska, Part 2: families Trachyleberididae, Hemicytheridae, Loxoconchidae, Paracytherideidae. United States Geological Survey Professional Paper, 1531:1-47.

Coimbra, J.C.; Carreño, A.L. \& Michelli, M.J. 1999a. Taxonomía y zoogeografía de la familia Cytheruridae (Ostracoda) de la plataforma continental ecuatorial de Brasil. Iheringia, Série Zoologia, 87:117-142.

Coimbra, J.C.; Pinto, I.D.; Würdig, N.L. \& do Carmo, D.A. 1999b. Zoogeography of Holocene Podocopina (Ostracoda) from the Brazilian Equatorial shelf. Marine Micropalaeontology, 37:365-379. doi:10.1016/S0377-8398(99)00025-0

Cronin, T.M. 1988. Evolution of marine climates of the U. S. Atlantic Coast during the past four million years. Philosophical Transactions of the Royal Society of London, Series B, Biological Sciences, 318:661-678. doi:10.1098/rstb.1988.0029
Horne, D.J.; Cohen, A. \& Martens, K. 2002. Taxonomy, Morphology and Biology of Quaternary and Living Ostracoda. In: J.A. Holmes \& A.R. Chivas (eds.) The Ostracoda: applications in Quaternary Research, Washington, D.C., American Geophysical Union, p. 5-36 (Geophysical Monograph Series 131).

ICZN. 2000. International Code of Zoological Nomenclature. Fourth Edition. Available at https://www.iczn.org/the-code/ the-international-code-of-zoological-nomenclature/the-codeonline/; accessed on 07/10/2020.

Machado, C.P.; Coimbra, J.C. \& Bergue, C.T. 2020. Provinciality of Ostracoda (Crustacea) in the northeastern and eastern Brazilian shelves based on neontological and paleontological analyses. Revista Brasileira de Paleontologia, 23:3-31. doi:10.4072/ rbp.2020.1.01

McKenzie, K.G. \& Swain, F.M. 1967. Recent Ostracoda from Scammon Lagoon, Baja California. Journal of Paleontology, 41:281-305.

Puckett, T.M. 2008. Ostracoda as indicators of vertebrate environments in the Middle Eocene Guys Hill Formation of Jamaica. Micropaleontology, 54:139-158.

Purper, I. \& Ornellas, L.P. 1987. The genus Paracytheridea (Ostracoda) in the Northern/Northwestern Brazilian continental shelf. Pesquisas, 20:103-124. doi:10.22456/1807-9806.21675

Received in 24 July, 2020; accepted in 08 September, 2020. 